DOI: https://doi.org/10.34069/AI/2021.40.04.22

\title{
Cassation filters in administrative judicial procedure: a step in a chasm or a novel that ukrainian society expected?
}

\section{Касаційні фільтри в адміністративному судочинстві: крок до прірви чи новела, яку чекало українське суспільство?}

Received: April 10, 2021

\begin{abstract}
The purpose of the article is to characterize the grounds for the use of "cassation administrative filters" as part of the mechanism for exercising the right of an individual to cassation appeal against a court decision in a public law dispute. The subject of research is the peculiarities of cassation review of decisions in administrative proceedings. Methodology: The methodological basis for the article are general and special methods of legal science, in particular: the method of dialectical analysis, the method of prognostic modeling, formal and logical, normative and dogmatic, sociological methods. The results of the study: The current regulations on the right of an individual to cassation appeal against court decisions in administrative proceedings by characterizing the existing procedural filters are analyzed. Practical implication: Based on the study of the case law, the types of administrative cassation filters applied by the courts when reviewing the decisions are identified. Value / originality: It is proved that achieving the effectiveness of the application of cassation administrative filters
\end{abstract}

Accepted: May 16, 2021

Written by:

Drozd Oleksii ${ }^{33}$

https://orcid.org/0000-0002-4514-6594

Dorokhina Yuliia ${ }^{84}$

https://orcid.org/0000-0002-2799-3933

Leheza Yuliia ${ }^{85}$

https://orcid.org/0000-0002-4896-3178

Smokovych Mykhailos

https://orcid.org/0000-0003-1710-4044

Zadyraka Natalia ${ }^{87}$

https://orcid.org/0000-0002-5866-7612

\footnotetext{
83 Doctor of Law, Associate Professor, Acting Head of the Department of Doctorate and Post-graduate Studies of the National Academy of Internal Affairs, Ukraine.

${ }^{84}$ Doctor of Law, Professor, Professor of the Department of Administrative Law and Procedure of Taras Shevchenko National University of Kyiv, Ukraine.

${ }^{85}$ Doctor of Law, Professor, Professor Department of Civil, Economic and Environmental Law of the National Technical University "Dnipro Polytechnic", Ukraine.

${ }^{86}$ Doctor of Law, Honored Lawyer of Ukraine, Associate Professor of the Department of State and Legal Disciplines of the National University Ostroh Academy, Ukraine.

${ }^{87}$ Doctor of Law, Professor, Associate Professor of Administrative Law and Procedure Department of the Institute of Law of Taras Shevchenko National University of Kyiv, Ukraine.
} 


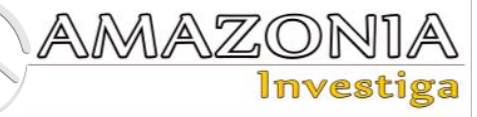

requires a high level of professionalism, which ensures the proper implementation of the individual's right to file a cassation appeal, and developing the unified approach to the use of assessment categories.

Key words: cassation filters, administrative proceedings, Code of Administrative Procedure, Supreme Court of Ukraine, court case.

\section{Introduction}

The creation of the system of administrative justice in Ukraine is aimed at ensuring the function of judicial control over the activities of executive bodies and other actors of public administration. The exercise of the function of judicial control by administrative courts should be performed in compliance with the requirements of the courts for the consideration and settlement of public law disputes. And if the consideration and resolution of administrative disputes belongs to the jurisdiction of the courts of first instance, then ensuring the right of a party to a public dispute to appeal a court decision is implemented by filing appeals or cassation. At the same time, consideration of the case in cassation proceedings pursues the goal of ensuring the correct application of procedural and substantive law, propriety of the implementation of their provisions in terms of compliance with regulatory requirements of general relations, including in the exercise of public administration.

Substantial updating of procedural legislation of Ukraine, which was initiated in 2017 with the adoption of the Law of Ukraine "On Amendments to the Commercial Procedure Code of Ukraine, Civil Procedure Code of Ukraine, Code of Administrative Procedure of Ukraine and other legislation" (Law No. 2147-VIII, 2017), was aimed at decongesting the national judicial system, the achievement of the unity of judicial practice, which, in particular, was associated with the normative consolidation of the grounds for exercising the right to appeal, including the definition of circumstances limiting access to administrative proceedings by the court of cassation.

Thus, the purpose of the study is to characterize the grounds for the use of "cassation administrative filters" as part of the mechanism for exercising the right of a person to cassation against court decision in a public law dispute. належну реалізацію права особи на подання касаційної скарги та вироблення єдності підходів до застосування оцінних категорій.

Ключові слова: касаційні фільтри, адміністративне судочинство, Кодекс адміністративного судочинства, Верховний Суд України, судова справа.

\section{Methodology}

The methodological basis for the research of the institute of "cassation administrative filters" as a component of the mechanism of realization of the person's right to administrative appeal is a set of methods of scientific knowledge, in particular, the method of dialectical analysis, method of prognostic modeling, formal and logical method, normative and dogmatic method, sociological method.

The application of the method of dialectical analysis allowed to determine the system of grounds for the application of restrictions on the access to the examination of a public-law dispute by way of cassation.

The task of establishing the essence and significance of the application of cassation administrative filters in the system of guarantees to prevent manifestations of abuse of procedural rights was achieved by applying formal and logical method.

Sociological method was used when considering the case law concerning the features of cassation administrative filters when reviewing court decisions.

With the help of normative and dogmatic method, the content of normative-legal acts of domestic legislation regulating the issue under study was analyzed.

The method of prognostic modeling was useful in determining the prospects for the implementation of cassation administrative filters in Ukraine.

\section{Literature Review}

Judicial control is one of the most important elements of the mechanism of protection of the rights, freedoms and interests of individuals, the rights and legitimate interests of legal entities from violations from the part of public officials. Administrative proceeding is called upon the 
protection of the rights and freedoms of individuals and legal entities from abuse by public authorities, local governments and their officials.

Pysarenko (2016, p. 260) states that cassation review of court decisions is one of the national means of judicial protection of the rights of individuals in the public sphere.

Ulmer (2014, p. 169) points out that cassation review in administrative proceedings is an optional procedural stage, which is a set of administrative procedural rules governing procedural relations related to the verification of the legality of court decisions of the court of first instance after their review on appeal, as well as court decisions of the appellate court in whole or in part.

Halunko, Dikhtiievskyi, Kuzmenko and Stetsenko (2018, pp. 318-322) suggest that cassation proceedings are regulated by the rules of administrative procedure law of the court of cassation to verify the legality of court decisions that have entered into force, in connection with the incorrect application of substantive law or violation of procedural law by the courts of first or (and) appellate instances.

Stafiichuk (2020, p. 318) define cassation review in administrative proceedings as one of the stages of the administrative process, which lies in reviewing the decisions, individual rulings of the court of first instance after appellate review of the case, rulings of the appellate court in whole or in part in respect of incorrect application of the rules of substantive law or violation of procedural law by the Supreme Court of Ukraine in cases established by law.

Uhler (1942, p. 13) devoted his study to the examination of the content of the doctrine of the separation of powers with a view to establishing the nature and extent of its bearing upon the problem of review of and relief from administrative action.

Zrvandyan (2016, p. 9) proves that administrative proceeding is a guarantee of the protection of the rights of individuals against unlawful decisions of public officials. Cessation review within this procedure is the warrant that the judgment will be reviewed by a competent, independent and impartial court or tribunal.

Putri (2019) states the French administrative justice is self-established and can serve as an example for other countries. So he aims at studying its features, as well as its main principle - the absolute competence.

\section{Results and Discussion}

Consideration of cassation appeal in an administrative case usually belongs to the jurisdiction of the Administrative Court of Cassation of the Supreme Court of Ukraine, but a number of administrative cases are brought before the Grand Chamber of the Supreme Court of Ukraine as a court of cassation; such public disputes are disputes that are considered and resolved by administrative courts of appeal as the courts of first instance according to Part 3, Article 22 of the Code of Administrative Procedure of Ukraine (hereinafter - CAP of Ukraine) (Law No. 2747-IV, 2005). It is obvious that a number of administrative disputes have been referred to by the legislature as disputes requiring, first and foremost, the consideration of interests of the territorial community of the region, and hence - the increased degree of public interest, which led to the designation of the administrative courts of appeal as the court of first instance. Such cases, in accordance with the provisions of current administrative procedure legislation, are disputes over the alienation of land and real estate located on it, in connection with public necessity; disputes arising in the area of public-private partnership; disputes related to public tenders, which result in the election of a private partner, as well as related to the concession tender.

The relevant amendments to the CAP of Ukraine (Law No. 2747-IV, 2005) set limits on the exercise of the right to cassation. Thus, let's analyze the current regulations on the right of cassation against judicial decisions in administrative cases by characterizing the existing procedural filters.

First of all, it should be noted that according to Part 2, Art. 13 of the CAP of Ukraine (Law No. 2747-IV, 2005) no appeal may be lodged in cassation against a first-instance decision without a review of that decision.

The right to cassation appeal against court decisions is accessible to a certain number of actors. Thus, Part 1, Art. 328 of the CAP of Ukraine (Law No. 2747-IV, 2005) stipulates that the parties to the case, as well as the persons who are not involved in the case, but the court has decided on their rights, freedoms, interests and (or) responsibilities, have the right to appeal in cassation against the decision of the court of first instance after the appeal review, as well as the 


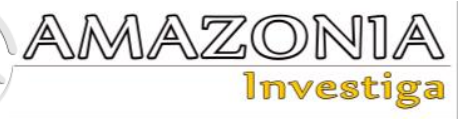

decision of the appellate court in whole or in part in the cases specified by this Code.

As one can see, the actors who are entitled to file a cassation appeal are:

1) persons involved in the case;

2) persons who are not involved in the case, if the court has decided on their rights, interests and / or responsibilities.

In this regard, the main issue in the court's decision on commencement is to clarify the circumstances that may be grounds for allowing persons who did not participate in the case to appeal in cassation against the decision of the court of previous instances.

The case № 640/17/19 (Judgment of the Supreme Court of Ukraine 2020(1)) can serve as an example for this statement. Thus, in January 2019 PERSON_1 filed a lawsuit against the Embassy of Ukraine in Canada, in which the first asked to make the actions of the Embassy of Ukraine in Canada to provide information for the period March 2016 - July 2018 on the existence of criminal proceedings in the territory of Ukraine against PERSON_1 illegal.

The complaint was based on the submission of letters to the Department of Foreign Affairs, Trade and Development of Canada by the respondent, containing the information on conducting pre-trial investigations of the plaintiff by the Prosecutor General's Office of Ukraine and on the fact that the plaintiff is suspected of having committed criminal offences. Considering that the information provided in the letters was incorrect, the plaintiff brought a lawsuit

The District Administrative Court of Kyiv by the decision of February 25, 2019, upheld by the decision of the Sixth Administrative Court of Appeal of May 16, 2019, granted the claim in full.

On August 14, 2019, a lawyer filed an appeal against the decision of the District Administrative Court of Kyiv of February 25, 2019 in the interests of PERSON_2, which did not participate in the case, but in respect of which the court decided on the rights, freedoms, interests and (or) responsibilities.

Having considered the application of PERSON_1 to discontinue the appeal proceedings, the Sixth Administrative Court of Appeal by the decision of September 30, 2019 granted the claim and closed the appeal proceedings on appeal of the PERSON_2 against the decision of the District Administrative Court of Kyiv from 25 February 2019 in case № 640/17/19. The said decision of the appellate court was motivated by the fact that the resolution of the dispute within this case does not concern the rights, freedoms, interests and (or) obligations of PERSON_2.

Disagreeing with the above court decision, the lawyer filed a cassation appeal in the interests of PERSON_2. In making its decision, the Supreme Court proceeded from the fact that in this case PERSON_2 was not the persons engaged in the case and the court did not decide on the rights and obligations of PERSON_2.

When closing the appeal proceedings on appeal of the PERSON_2 against the decision of the court of the first instance, the Sixth Administrative Court of Appeal indicated that the decision in case № 640/17/19 cannot serve as an unconditional confirmation of the violation of the rights and legitimate interests of PERSON_2.

A similar view was expressed by the Supreme Court in some other decisions. According to these decisions the persons who were not involved in the case have the right to appeal only those court decisions that directly establish, change or terminate the rights and obligations of these persons.

Besides, the Supreme Court emphasized that, unlike the party to the case, a person who is not involved in the case, should prove that it has a legal connection with the parties to the dispute or the judgment directly by substantiating the following criteria: the decision of the court as to its right, interest, duty, and such connection must be obvious and unconditional, not possible.

Therefore, such a right has a person who did not participate in the case, but the motivating part of the decision contains the court's conclusions on the rights, interests and / or responsibilities of this person, or the operative part contains the decision about the rights, interests and / or responsibilities of such person. Any other legal relationship between the complainant and the parties to the dispute cannot be taken into account (Urkevych, 2021).

This fact is also emphasized by Prytyka and Kravtsov (2019, p. 689). The scientists stress that the right of appeal and cassation is granted to the participants involved in the case, as well as to those persons who did not take part in the case if 
the court decided on their rights, freedoms, interests and/or duties.

In accordance with the provisions of Part 2, 3, Art. 328 of the CAP of Ukraine (Law No. 2747IV, 2005), a cassation appeal may be lodged against such judicial decisions on appeal, as:

a) decisions of the court of the first instance on securing the claim, the replacement of the measure of securing the claim, decision to return the application to the plaintiff (applicant), refusal to commence proceedings, leaving the claim (application) without consideration, dismissal of the case, refusal to commence proceedings on review of a court decision on newly discovered or exceptional circumstances, refusal to grant an application for review of a court decision on newly discovered or exceptional circumstances; replacement of a party to the case (procedural succession) or a party to enforcement proceedings;

b) decisions of the court of appellate instance on refusal to commence or close appellate proceedings, on return of appeal, on suspension of proceedings, on securing the claim and replacement of the measure of securing the claim, on refusal to make additional decision, on clarification of the decision or refusal to clarify the decision; on amending or refusing to amend the decision, on returning the application for review on newly discovered or exceptional circumstances, on refusing to open proceedings on newly discovered or exceptional circumstances, on refusing to grant the application for review of the court decision on newly discovered or exceptional circumstances, on replacement of the party in the case, on the imposition as the form of procedural coercion, selected decisions.

Thus, in fact, the CAP of Ukraine (Law No. 2747-IV, 2005) contains an exclusive list of court decisions that can be appealed in cassation. However, there are different points of view on this issue in judicial practice.

Let's consider the case № 420/7281/19 (Judgment of Odesa District Administrative Court, 2020) in this respect. According to the materials of this case Velykomykhailivska village council of Velykomykhailivskyi district of Odesa region appealed to the Supreme Court disagreeing with the decisions of the courts of first and appellate instances in terms of imposing a fine.
According to the decision of the Supreme Court of July 30, 2020 the cassation proceedings were commenced. However, on September 4, 2020, the proceedings were closed on the grounds that the procedural law does not provide for the possibility of cassation appeal against the decision of the court of first instance on imposing fines and on other issues of judicial control over the execution of court decisions in administrative cases under Article 382 of the CAP of Ukraine (Law No. 2747-IV, 2005) after its review by the Court of Appeal, as well as the decision of this court.

The court also pointed out that since the appealed judgments in this case cannot be reviewed by the Supreme Court as a court of cassation in administrative cases in the manner prescribed by Chapter 2, Section 3 of the CAP of Ukraine (Law No. 2747-IV, 2005), the cassation proceedings to be closed as erroneously opened according to Part 2, Article 339 of this Code.

However, one of the judge of the panel had a separate opinion; he indicated that by initiating cassation proceedings in the case the Supreme Court was obliged to examine the merits of the cassation appeal and to make the appropriate decision with specific reasons for such a decision.

The judge noted that using all available procedural mechanisms, the Supreme Court is obliged to respond to any court decisions that do not comply with the principle of consistency and uniformity of practice. It is important that the constitutional right of a person to "cassation appeal of a court decision in cases specified by law" does not prohibit the Supreme Court from conducting a cassation review of a court decision if there is an obvious purpose to "ensure the stability and unity of judicial practice"; on the contrary, such situation obliges the Court to conduct a review in cassation to ensure that the quality of judicial practice in Ukraine (its stability and unity, compliance by all courts with the position of the Supreme Court. The refusal of the Supreme Court to ensure the stability and unity of judicial practice through undermines the authority of the Supreme Court and confidence in the judiciary as a whole.

According to Part 4, Art. 328 of the CAP of Ukraine (Law No. 2747-IV, 2005) the grounds for the cassation of court decisions referred to in Part 1 of Art. 328 of the CAP of Ukraine are incorrect application of substantive law or violation of procedural law by the court in the following cases: 


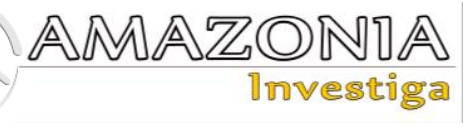

1) if the appellate court applied the rule of law in the challenged judgment without taking into account the conclusion on the application of the rule of law in such legal relations, set out in the decision of the Supreme Court, except where there is a Supreme Court decision to cede such a finding;

2) if the appellant justified the need to deviate from the conclusion on the application of the rule of law in such legal relations, set out in the decision of the Supreme Court and applied by the appellate court in the challenged judgment;

3) if there is no opinion of the Supreme Court on the application of the rule of law in such legal relations;

4) if the court decision is appealed on the grounds provided for in Parts 2, 3, Article 353 of this Code.

The grounds for cassation appeal against court decisions referred to in Parts 2, 3, Article 353 of this Code (Law No. 2747-IV, 2005) are misapplication of substantive law or violation of procedural law by the court.

Therefore, during the cassation appeal against court decisions referred to in Part 1, Art. 328 of the CAP of Ukraine (Law No. 2747-IV, 2005), the justification of the misapplication of substantive law or violation of procedural law by the court (courts) should be provided in conjunction with a reference to the relevant paragraph (paragraphs) of Part 4, Art. 328 of the CAP of Ukraine (Law No. 2747-IV, 2005).

In rendering judgment on the case № 580/2746/19 (Judgment of the Supreme Court of Ukraine 2020(2)), the Supreme Court stated that the analysis of the construction of Part 4, Art. 328 of the CAP of Ukraine gives grounds for the conclusion that this rule contains two conditions, which constitute the content of the category "grounds for cassation appeal against court decisions".

The essence of the first of these conditions is that the cassation appeal should indicate what constitutes an incorrect application of the rules of substantive law or the violation of the rules of procedural law when first instance and appellate courts hear appealed judicial decisions. This condition should be met in cassation appeals against all judicial decisions specified in Part 1, Art. 328 of the CAP of Ukraine(Law No. 2747IV, 2005) (the decisions of the court of first instance after the review, as well as decisions of the court of appeal).
In turn, the second condition stipulates that the person filing a cassation appeal, in addition to indicating the incorrect application of substantive law and (or) violation of procedural law by the court (courts), should also cite one of the circumstances provided for in Par. 1 - 4, Part 4, Art. 328 of the CAP of Ukraine (Law No. 2747IV, 2005).

Thus, the grounds for appeal in cassation against judgments handed down in cases other than those of minor complexity are, firstly, the facts of incorrect application of substantive law and (or) violation of procedural law by the court (courts), and secondly, justification of the existence of one or more circumstances provided for in Par. 1 - 4, Part 4, Art. 328 of the CAP of Ukraine (Law No. 2747-IV, 2005).

Instead, according to the rules of Par. 2, Part 5 of Art. 328 of the CAP of Ukraine (Law No. 2747IV, 2005) no appeal may be lodged against judgments handed down in cases of minor complexity and other cases, which are dealt with under the expedited rules (except for cases that are considered in accordance with this Code under the rules of general proceedings), unless:

a) the appeal in cassation concerns the aspect of law, which is fundamental for the formation of unified law enforcement practice;

b) a person who files a cassation appeal, in accordance with this Code, is deprived of the opportunity to challenge the facts established by the court's decision in another case;

c) the case is of significant public interest or is of exceptional importance for the party to the case, who files a cassation appeal;

d) the court of first instance considered the case to be of minor complexity erroneously.

Thus, the analysis of the norm of Par. 2, Part 5, Art. 328 of the CAP of Ukraine (Law No. 2747IV, 2005)attests to the fact that during the cassation appeal against the judicial decisions issued in cases of minor complexity and other cases dealt with under the summary rules (except for cases that under this Code are considered under the rules of general proceedings), it is obligatory for the appellant to argue in cassation that there is one or more circumstances, the list of which is set out in subparagraphs "a", "b", "c" and "d" of Par., Part 5, Article 328 of the CAP of Ukraine (Law No. 2747-IV, 2005).

At the same time, the court of cassation emphasizes that the condition regarding the 
indication in the cassation appeal of the grounds for incorrect application of substantive law or violation of procedural law during the adoption of the courts of first and (or) appellate instances of the appealed court decisions, enshrined in Part 4, Art. 328 of the CAP of Ukraine (Law No. 2747-IV, 2005), is general and should be observed when reviewing all court decisions, defined by Part 1, Art. 328 of the CAP of Ukraine (Law No. 2747-IV, 2005), i.e. such a requirement is applied to any decisions of the court of first instance after the appellate review of the case and the decisions of the appellate court, regardless of whether the case was dealt with under the summary rules or under the rules of general proceedings.

Therefore, firstly, in addition to stating the circumstances enshrined in Par. "a" - "g", Part 5, Art. 328 of the CAP of Ukraine (Law No. 2747IV, 2005), a person who files a cassation appeal in cases of minor complexity and other cases dealt with under the summary rules (except for cases that are considered in accordance with this Code under the rules of general claim proceedings); secondly, this person should indicate the facts of misapplication the rules of substantive law and / or violation of procedural law, which the court (courts) allowed when taking the appealed court decisions, as well as to substantiate what exactly constitutes such a violation or misapplication of the law and the way it has affected the adoption of these court decisions.

Such grounds are set out in the cassation appeal with mandatory indication of the specific conclusions of the court, whose decision is being appealed, while indicating the provisions (paragraph, part, article) of the law or other legal act applied by this court in formulating the opinion. This allows the court of cassation to check the correctness of the application of substantive law and (or) compliance with procedural law by court (courts) in a particular case according to Art. 341 of the CAP of Ukraine(Law No. 2747-IV, 2005). Besides, the appellant should clearly indicate which rule of law was applied by the courts of first and (or) appellate instances without taking into account the opinion on the application of the rule of law in such legal relations set out in the Supreme Court ruling, except where there is a Supreme Court ruling derogating from such a finding or to substantiate the need to derogate from the conclusion on the application of the rule of law in such legal relations, set out in the decision of the Supreme Court and applied by the appellate court in the challenged court decision.
The court of cassation cannot independently determine the grounds for cassation appeal; such an obligation is imposed on the person appealing the court decisions, since the order for the commencement of cassation proceedings specifies the ground (grounds) for the commencement of cassation proceedings (Part 3, Article 334 of the CAP of Ukraine) (Law No. 2747-IV, 2005), and, subsequently, the court of cassation reviews court decisions within the limits of the grounds and requirements of the cassation appeal, which became the basis for the commencement of cassation proceedings (Part 1, Article 341 of the CAP of Ukraine) (Law No. 2747-IV, 2005).

If the appellant considers that the courts have violated the rules of procedural law on the failure to examine the evidence gathered in the case, on the incomplete establishment of the facts of the case, or the establishment of material circumstances on the basis of inadmissible evidence, the cassation appeal should specify either the circumstances established on the basis of inadmissibility evidence and the proof of their inadmissible, or the evidence gathered in the case, which was not examined by the court, but could give grounds for proving that this court has violated procedural law.

The cassation appeal should contain the reference to specific violations of the relevant rule (norms) of law or inadmissibility of its (their) application. The complainant should indicate the specific violations that are grounds for revocation or change of the court decision (decisions), which, in his (her) opinion, were committed by the court in its (their) adoption, and provide arguments to justify his (her) view.

At the same time, the issue of the grounds for cassation appeal is acute, when the appellate court applied the rule of law in the appealed court decision without taking into account the conclusion on its application in similar legal relations set out in the Supreme Court ruling, except where there is a Supreme Court ruling derogating from such a finding.

The Law of Ukraine "On the Judiciary and the Status of Judges" (Law No. 1402-VIII-2016) stipulates that the conclusions on the application of legal norms set forth in the rulings of the Supreme Court are taken into account by other courts when applying such legal norms (Part 6 of Article 13 of this Law). Thus, failure to take account of the legal opinions of the Supreme Court may constitute grounds for cassation appeal against court decisions. Moreover, such 


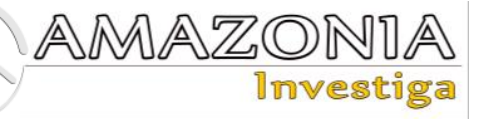

conclusions should be drawn in a case in which a cassation review has already taken place and should cover the application of the same rule of law as applied in the challenged judgments to similar legal relationships.

As it becomes clear, the key criterion in this case is the term "similar legal relationship". According to the dissenting opinion of Hudyma, who is the judge of the Grand Chamber of the Supreme Court in the case №357 / 3258/16-ts (Judgment of the Supreme Court of Ukraine 2018), the procedural law does not require identity, but indicates the need to establish only the similarity of legal relations. The similarity of legal relations should be established simultaneously by three criteria: subjective, objective and, so to speak, substantive. Moreover, similarity found at the same time according to three criteria, could indicate their identity (the same type of subjects, the same type of object and the same rights and obligations).

However, Par. 1, Part 4, Art. 328 of the CAP of Ukraine (Law No. 2747-IV, 2005)states about the failure to take into account the findings of the Supreme Court only by the appellate court, and there is no mention of the court of first instance.

Moreover, as emphasized in the special literature, the issue of non-consideration by the courts of first and appellate instances of the conclusions on the application of the rules of law set forth in the decisions of the Supreme Court of Ukraine as grounds for cassation of relevant court decisions remains open (Urkevych 2021).

The next ground for cassation appeal of court decisions is the situation when the appellant reasonably justified the need to deviate from the conclusion on the application of the rule of law in such legal relations, set out in the Supreme Court and applied by the appellate court in the challenged judgment (Par. 8, Part 4, Art. 328 of the CAP of Ukraine) (Law No. 2747-IV, 2005).

Deviation from the opinion should be understood as either a complete refusal of the Supreme Court from its previous opinion in favor of another one or specification of the preliminary opinion using appropriate interpretations of legal norms.

Therefore, the appellant should indicate in the cassation appeal that the existing conclusion of the Supreme Court on the application of the rule of law in such legal relations needs to be changed; it is advisable to depart from it taking into account the specific circumstances of the case. The motivation of such a petition of the appellant is assessed by the court of cassation both when applying the above procedural filter when deciding on the opening of cassation proceedings in the case, and when conducting a cassation review of court decisions.

An example of the application of this filter is the court decision in case № 320/1945/20 (Judgment of the Supreme Court of Ukraine (2021(2)). The Supreme Court justified that if a cassation appeal is filed under Par. 2, Part 4, Article 328 of this Code, it should contain substantiation of the need to deviate from the conclusion on the application of the rule of law in such legal relations, set out in the decision of the Supreme Court.

The appellant indicates the need to deviate from the conclusion on the application of the rule of law in such legal relations, set out in the Supreme Court and applied by the appellate court in the challenged judgment (Par. 2, Part 4, Article 328 of the CAP of Ukraine) (Law No. 2747-IV, 2005).

However, such justification contradicts the legal content of Par. 2, Part 4, Article 328 of the CAP of Ukraine. After analyzing the case file, the Supreme Court noted that the appellant arbitrarily identified the notion of deviation from the Supreme Court's conclusions in such legal relations with the irrelevance of their application by the court to the disputed legal relationship, and did not provide a legal justification for the deviation.

On the basis of the analysis carried out, the Supreme Court concluded that the cassation appeal had to be returned to the applicant.

Another ground for cassation appeal against court decisions is the lack of an opinion of the Supreme Court on the application of the rule of law in such legal relations (Par. 3, Part 4, Article 328 of the CAP of Ukraine) (Law No. 2747-IV, 2005). In this case, the appellant should prove certain uniqueness of his (her) case, to substantiate that the dispute in the case arose in a legal relationship such as that which had not yet been analyzed in previous decisions of the Supreme Court.

Thus, the Supreme Court points out that in case of filing a cassation appeal against the court decision referred to in Parts 2, 3 of the Article 328 of this Code, the cassation appeal should note the reasoning behind the incorrect application of substantive law or violation of procedural law, which led to the adoption of illegal court decision (decisions). 
However, if a party formally invokes the court's erroneous application of the rules of substantive and procedural law, cites the rules of law governing the dispute and his (her) arguments are reduced to the description of the circumstances established by the courts in this case and their reassessment, which goes beyond the powers of the court of cassation, the Supreme Court notes the following: "in the cassation appeal, the appellant must state the reasons for disagreement with the court decision, taking into account the grounds for its cancellation or amendment (Articles 351 - 354 of the CAP of Ukraine) (Law No. 2747-IV, 2005), indicating the specific conclusions of the court, whose decision is appealed, while indicating the law (paragraph, part, article), which was incorrectly applied by this court in making the relevant conclusion. In addition, the appellant should clearly indicate which rule of law was applied by the courts of first and (or) appellate instances without taking into account the conclusion on the application of the rule of law in such legal relations set out in the Supreme Court ruling, except where there is a Supreme Court ruling derogating from such a finding or to substantiate the need to derogate from the conclusion on the application of the rule of law in such legal relations, set out in the decision of the Supreme Court and applied by the appellate court in the challenged court decision.

In case of filing a cassation appeal under Par. 3, Part 4, Article 328 of the CAP of Ukraine (Law No. 2747-IV, 2005) (there is no conclusion of the Supreme Court on the application of law in such legal relations), the appellant should clearly indicate which rule of law was applied incorrectly by the courts of first and (or) appellate instances and to substantiate the misapplication of the relevant rule of law and the way the relevant rule should be applied".

Therefore, it is expedient to emphasize that the CAP of Ukraine (Law No. 2747-IV, 2005) requires clear indication of the grounds on which the cassation appeal is filed, taking into account the provisions of Par. 3, Part 4, Article 328 of this Code with the indication of full data of the corresponding resolution of the Supreme Court of Ukraine.

In the case of a cassation appeal under Par. 2, Part 4, Article 328 of the CAP of Ukraine (Law No. 2747-IV, 2005), it should include the decision of the Supreme Court, which sets out the conclusion on the application of law in such legal relations, which was not taken into account in the contested decision. When filing a cassation appeal on the basis of Par. 2, Part 4, Article 328 of the CAP of
Ukraine (Law No. 2747-IV, 2005), there should be the justification of the need to derogate from the conclusion on the application of the rule of law in such legal relations, set out in the Supreme Court.

In view of the above, it is expedient to cite the decision in case № 826/12668/17 (Judgment of the Supreme Court of Ukraine 2021(1)), in which the panel of judges drew attention to the fact that the plaintiff did not substantiate and specify what exactly are the grounds for derogation from the legal position of the Supreme Court.

The basis for cassation appeal against court decisions can be a number of procedural violations, which are defined as grounds for revocation of court decisions of the courts of first and appellate instances under Parts 2, 3, Art. 353 of the CAP of Ukraine (Par. 4, Part 4, Article 328 of the CAP of Ukraine) (Law No. 2747-IV, 2005).

In this regard, it is appropriate to emphasize that when filing a cassation appeal in accordance with Par. 1, Part 2, Art. 353 of the CAP of Ukraine (Law No. 2747-IV, 2005) (if the court has not examined the evidence collected in the case), the grounds for cassation appeal, provided for in Par. 1, 2, 3, Part 2, Article 328 of the CAP of Ukraine (Law No. 2747-IV, 2005), should also be substantiated. In other words, the grounds for cassation appeal against court decisions, enshrined in Par. 1, Part 2, Art. 353 of the CAP of Ukraine (Law No. 2747-IV, 2005), is always applied in conjunction with Par. 1, 2, 3, Part 2, Article 328 of the CAP of Ukraine (Law No. 2747-IV, 2005).

Therefore, the cassation appeal against court decisions on the grounds of Par. 1, 2, 3, Part 2, Article 328 of the CAP of Ukraine (Law No. 2747-IV, 2005), other than a reference to the court's improper application of substantive law and violation of rules of procedural law, should contain the following information.

Firstly, the precise wording of the court of appeal's conclusion on the application of the rule of law indicating this rule of law and the content of the legal relations, in which this rule is applied, with which the complainant disagrees. Besides, the reference should be made to the rulings of the Supreme Court, which made a different conclusion on the application of the same rule of law in similar legal relations, with a justification for the inconsistency of the challenged court decision, which is formed in law enforcement practice in similar legal relations. 


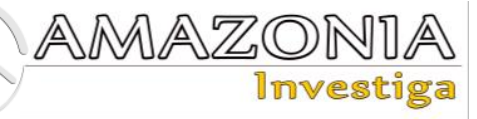

Secondly, the substantiation of the need to derogate from the conclusion on the application of the rule of law set out in the decision of the Supreme Court and applied by the appellate court in the challenged court decision, with a clear indication of the rule of law (paragraph, part of the article), description of legal relations and substantiation of motives of such deviation.

Thirdly, an indication of a rule of law for which there is no conclusion that it has been applied with specification of the content of the legal relations in which this conclusion does not exist and justification of the need to form a single law enforcement practice on this rule to properly resolve the case.

Another type of procedural filter is the list of cases that are not subject to cassation appeal, in particular under Part 5 of Art. 328 of the CAP of Ukraine (Law No. 2747-IV, 2005):

1) decisions, rulings of the court of first instance and resolutions, rulings of the court of appellate instance in cases, in which decisions are subject to review on appeal by the Supreme Court;

2) court decisions in cases of insignificant complexity and other cases dealt with under the Summary Rules (except for cases that are considered in accordance with the rules of general claim proceedings), except in cases where:

a) the cassation appeal concerns the issue of law, which is fundamental for the formation of a unified law enforcement practice;

b) a person who files a cassation appeal, in accordance with this Code, has no opportunity to challenge the facts established by a judicial decision when considering another case;

the case is of significant public interest or is of exceptional importance for the party to the case, who files a cassation appeal;

The court of first instance considered the case to be of minor complexity erroneously.

These procedural instructions contain a number of evaluative concepts such as: "fundamental importance", "formation of a single law enforcement practice", "significant public interest", "exceptional importance for the party". Therefore, in a cassation appeal, the existence of such cases should be duly substantiated directly by the appellant. Accordingly, when the court of cassation decides on the commencement of cassation proceedings in the case, it is the credibility of the complainant's arguments that is evaluated.

\section{Conclusion}

At the same time, it should not be forgotten that for cases, in which court decisions are not subject to cassation as a general rule, more complex conditions for access to the court of cassation have been introduced. Thus, besides the existence of these cases, the complainant should additionally overcome the procedural filters established by the CAP of Ukraine to appeal the relevant types of court decisions. In other words, the cassation appeal should duly substantiate the position that a particular case is of exceptional importance to the party to the case, and the court's decisions were taken with the wrong application by the court of substantive law or violation of procedural law if there is an exceptional case of cassation.

Thus, achieving the effectiveness of the application of cassation administrative filters requires a high level of professionalism, which ensures the proper implementation of the individual's right to file a cassation appeal, developing the unified approach to the use of assessment categories, and completion of the reform of the administrative justice system. The solution of such procedural tasks will inevitably result in the realization of the idea of the functioning of the "court of law" in Ukraine, which, in fact, should be the Administrative Court of Cassation of the Supreme Court.

\section{References}

Halunko, V., Dikhtiievskyi, P., Kuzmenko, O. and Stetsenko, S. (2018). Administrative law of Ukraine: complete course: handbook. Kherson: OLDI-PLIUS.

Judgment of Odesa District Administrative Court (2020). Case No. 420/7281/19, Odesa, Ukraine, July 22, 2020. https://www.uacourt.openregister.info/okremiprotsesualni-pytannya-41451/inshi-skargy-tazayavy-v-protsesi-vykonannya-sudovykhrishen-ta-rishen-inshykh-organiv-posadovykhosib-41462? document $=90516713$

Judgment of the Supreme Court of Ukraine (2018). Case No. 357/3258/16-ts, Kyiv, Ukraine, February 08, 2018. https://zakononline.com.ua/courtdecisions/show/72150984

Judgment of the Supreme Court of Ukraine (2020(2)). Case No. 580/2746/19, Kyiv, Ukraine, July $31, \quad 2020$. 
http://od.reyestr.court.gov.ua/files/45/e530c2c6c 91e22fcc1772d0acb58a325.rtf

Judgment of the Supreme Court of Ukraine (2020(1)). Case No. 640/17/19, Kyiv, Ukraine, October 20 , 2020. https://verdictum.ligazakon.net/document/92334 412

Judgment of the Supreme Court of Ukraine (2021(1)). Case No. 826/12668/17, Kyiv, Ukraine, February 22, 2021. https://verdictum.ligazakon.net/document/95579 935?utm_source=biz.ligazakon.net\&utm_mediu $\mathrm{m}=$ news\&utm_content=bizpress05

Judgment of the Supreme Court of Ukraine (2021(2)). Case No. 320/1945/20, Kyiv, Ukraine, March 18, 2021. https://verdictum.ligazakon.net/document/94937 427

Law No. 2147-VIII. On the amendment of the code of commercial procedure of Ukraine, the code of civil procedure of Ukraine, the code of administrative procedure of Ukraine and other legislative acts. Official Gazette of the Verkhovna Rada of Ukraine, Kyiv, Ukraine, October 03, 2017. https://zakon.rada.gov.ua/laws/show/2147-

19\#Text

Law No. 1402-VIII. On the judiciary and the status of judges. Official Gazette of the Verkhovna Rada of Ukra ine, Kyiv, Ukraine, June 02, 2016. https://zakon.rada.gov.ua/laws/show/140219\#Text

Law No. 2747-IV. UKRAINE ADMINISTRATIVE COURT CODE. Official Gazette of the Verkhovna Rada of Ukra ine, Kyiv, Ukraine, July 06, 2005. https://zakon.rada.gov.ua/laws/show/274715\#Text
Prytyka, Y., \& Kravtsov, S. (2019). Review of Court Decisions: ¿Does Ukraine Guarantee the Right to a Fair Trial in Appeal? Amazonia Investiga, 8(23), 685-692. Retrieved from https://amazoniainvestiga.info/index.php/amazo nia/article/view/923

Putri, C.W. (2019). A Review on Administrative Justice Competencies in France. Rechstidee, $6(1)$.

https://rechtsidee.umsida.ac.id/index.php/rechtsi dee/article/view/90/701\#title-2

Pysarenko, N., ed. (2016). Administrative proceedings: handbook. Kharkiv: Pravo. https://pravo-

izdat.com.ua/image/data/Files/209/1-24.pdf

Stafiichuk, K. (2020). Legal nature of cassation proceedings in administrative proceedings of Ukraine. Juridical scientific and electronic journal, Num. 8, pp. 317 - 319. https://doi.org/10.32782/2524-0374/2020-8/78. http://lsej.org.ua/8_2020/80.pdf

Uhler, A. (1942). Review of administrative acts. Chicago: The University of Michigan Press. https://core.ac.uk/download/pdf/323028861.pdf Ulmer, M. (2014). Cassation proceedings in administrative judicial proceedings in Ukraine. (PhD Dissertation). Interregional Academy of Personal Management. Kyiv.

Urkevych, V. (2021). Procedural filters for cassation appeals against economic court decisions. Legal Gazette. https://supreme.court.gov.ua/supreme/prescentr/zmi/1092715/

Zrvandyan, A. (2016). Casebook on European fair trial standards in administrative justice. Council of Europe: Folke Bernadotte Academy. https://rm.coe.int/16807001c6 